\title{
Annual Report of preparatory work on the toxicological studies and animal feeding studies performed under the EFSA contract OC/EFSA/GMO/2014/01, Lot 2 during the period $1 / 3 / 2017$ to $27 / 11 / 2018$
}

Beltoft, Vibe Meister; Nørby, Karin Kristiane

Published in:

E F S A Journal

Link to article, DOI:

10.2903/sp.efsa.2019.EN-1586

Publication date:

2019

Document Version

Publisher's PDF, also known as Version of record

Link back to DTU Orbit

Citation (APA):

Beltoft, V. M., \& Nørby, K. K. (2019). Annual Report of preparatory work on the toxicological studies and animal feeding studies performed under the EFSA contract OC/EFSA/GMO/2014/01, Lot 2 during the period 1/3/2017 to $27 / 11 / 2018$. E F S A Journal, 16(2), [1586E]. https://doi.org/10.2903/sp.efsa.2019.EN-1586

\section{General rights}

Copyright and moral rights for the publications made accessible in the public portal are retained by the authors and/or other copyright owners and it is a condition of accessing publications that users recognise and abide by the legal requirements associated with these rights.

- Users may download and print one copy of any publication from the public portal for the purpose of private study or research.

- You may not further distribute the material or use it for any profit-making activity or commercial gain

- You may freely distribute the URL identifying the publication in the public portal 


\title{
Annual Report of preparatory work on the toxicological studies and animal feeding studies performed under the EFSA contract OC/EFSA/GMO/2014/01, Lot 2 during the period $1 / 3 / 2017$ to $27 / 11 / 2018$
}

\author{
Vibe Beltoft and Karin Nørby \\ National Food Institute, Technical University of Denmark
}

\begin{abstract}
This report describes the tasks performed in the period $1 / 3 / 2017$ to $27 / 11 / 2018$ under the EFSA contract OC/EFSA/GMO/2014/01, Lot 2 on toxicological studies and animal feeding studies included in applications for market authorisation of genetically modified feed/plants under Regulation (EC) No $1829 / 2003$. The tasks cover the check for study adherence to relevant EFSA guidance documents and to OECD Test Guideline no 407 (1995/2008), OECD Test Guideline no 408 (1998) and OECD Principles on Good Laboratory Practice. During the period covered by this report, preparatory work has been performed on six applications for GM plants submitted under Regulation (EC) No 1829/2003 for a total of three 28-day studies on newly expressed proteins and six 90-day studies in rodents on GM food/feed, using comprehensive checklist templates.
\end{abstract}

(c) National Food Institute, DTU, 2019

Key words: OC/EFSA/GMO/2014/01 Lot 2, GMO-toxicity, compliance

Question number: EFSA-Q-2018-00927

Correspondence: GMO@efsa.europa.eu 
National Food Institute

Suggested citation: Technical University of Denmark, Beltoft V and Nørby K, 2019. Annual Report of preparatory work on the toxicological studies and animal feeding studies performed under the EFSA contract OC/EFSA/GMO/2014/01, Lot 2 during the period 1/3/2017 to 27/11/2018. EFSA supporting publication 2019:EN-1586. 8 pp. doi:10.2903/sp.efsa.2019.EN-1586.

\section{ISSN: $2397-8325$}

(C) National Food Institute, DTU, 2019

Disclaimer: The present document has been produced and adopted by the bodies identified above as author(s). This task has been carried out exclusively by the author(s) in the context of a contract between the European Food Safety Authority and the author(s), awarded following a tender procedure. The present document is published complying with the transparency principle to which the Authority is subject. It may not be considered as an output adopted by the Authority. The European Food Safety Authority reserves its rights, view and position as regards the issues addressed and the conclusions reached in the present document, without prejudice to the rights of the authors. 
National Food Institute

\section{Summary}

This annual report provides a summary of the work performed by the National Food Institute at DTU (here defined as Contractor) in the context of the Framework Contract No OC/EFSA/GMO/2014/01 Lot 2, signed on 28/11/2013 (here defined as Framework Contract) for the period March 1, 2017 November 27, 2018.

In the context of the Framework Contract, the Contractor provided preparatory work on toxicological studies and animal feeding studies in the context of applications on genetically modified (GM) plants, in accordance with the deliverables defined in Lot 2 tasks.

Based on comprehensive checklists developed by the Contractor in collaboration with the EFSA GMO Unit, the Contractor has reviewed the adherence to respective relevant guidelines of studies related to six applications for GM plants submitted under Regulation (EC) No 1829/2003, and provided a complete overview of each study covering abstract, summary, statistics, reports of compliance and deviations to the respective relevant guidelines. This preparatory work was performed on three 28day studies on newly expressed proteins and six 90-day studies in rodents on GM food/feed. The aim of this work was to contribute to support the evaluation of GM plants submitted under Regulation (EC) No $1829 / 2003$ by the Panel on Genetically Modified Organisms (GMO). 


\section{Table of contents}

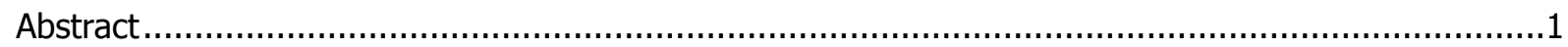

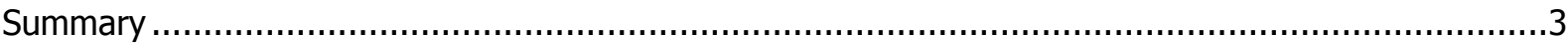

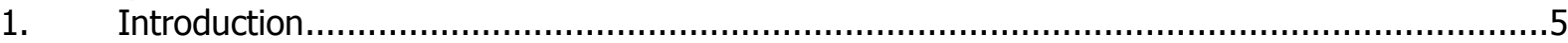

1.1. $\quad$ Background and Terms of Reference as provided by the requestor ...............................

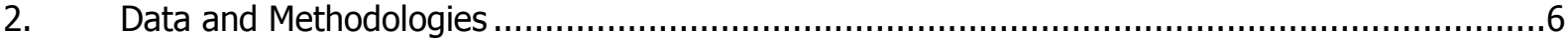

2.1. Data for Lot 2 - toxicological studies and animal feeding studies ..................................

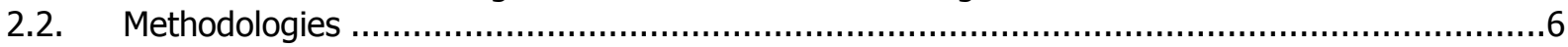

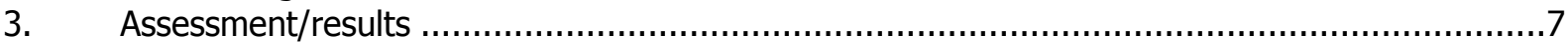

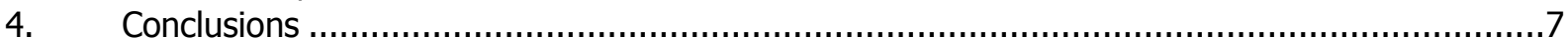

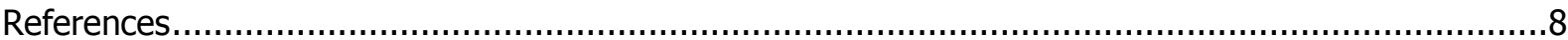


National Food Institute

\section{Introduction}

\subsection{Background and Terms of Reference as provided by the requestor}

The Implementing Regulation (EU) No 503/2013 specifies risk assessment requirements for applications for market authorisation of genetically modified (GM) plants and derived products. It also provides indications on the methodological approach to follow for the comparative (compositional, agronomic and phenotypic) assessment and for toxicological studies ${ }^{1}$.

With respect to the comparative assessment of GM plants and derived products, minimum requirements include the experimental design of field trials in order to ensure sufficient statistical power and reliable estimation of natural variability and the statistical analysis of the field trials carried out with the GM plant, the conventional counterpart and a set of non-GM reference varieties. The use of statistical mixed models and recommendations for the analysis of compositional, agronomic and phenotypic data from those field trials are further described in the Scientific Opinions on statistical consideration for risk assessment of GMOs and the Guidance for risk assessment of food and feed from genetically modified plants.

With regard to toxicological studies, general requirements are described in the Implementing Regulation (EU) No 503/2013, with reference to relevant regulations and guidelines for technical details, including Directive 2004/10/EC ${ }^{2}$, OECD Principles of $\mathrm{GLP}^{3}$, Regulation (EC) No 440/2008 ${ }^{4}$, the EFSA Scientific Committee Guidance on conducting repeated-dose 90 -day oral toxicity study in rodents on whole food/feed.

A call for a framework contract for the preparatory support for the statistical evaluation of the comparative assessment of GM plant field trials (LOT 1) and for the evaluation of toxicological studies for GM plant food/feed safety (LOT 2) has accordingly been launched by EFSA.

The purpose for Lot 2 of the contract OC/EFSA/GMO/2014/01 is to provide preparatory support to the EFSA GMO Panel evaluation of the adherence of toxicological studies and animal feeding studies, performed for the safety assessment of GM plants, to the appropriate EFSA guidance documents and standardised guidelines, and to the Implementing Regulation (EU) No 503/2013. The task does not include the adherence to other guidelines to which the applicant may have referred to in the study reports.

The contract was awarded by EFSA to National Food Institute, Technical University of Denmark (DTU).

Contract title: Preparatory support for the statistical evaluation of the comparative assessment of GM plant field trials and for the evaluation of toxicological studies for GM plant food/feed safety, LOT2: Toxicological studies and animal feeding studies.

Contract number: OC/EFSA/GMO/2014/01

\footnotetext{
${ }^{1}$ Commission Implementing Regulation (EU) No 503/2013 of 3 April 2013 on applications for authorisation of genetically modified food and feed in accordance with Regulation (EC) No 1829/2003 of the European Parliament and of the Council and amending Commission Regulations (EC) No 641/2004 and (EC) No 1981/2006.

2 EC, 2004. Directive 2004/10/EC of the European Parliament and of the Council of 11 February 2004 on the harmonisation of laws, regulations and administrative provisions relating to the application of the principles of good laboratory practice and the verification of their applications for tests on chemical substances. Official Journal of the European Union, L50, 44-59.

3 OECD, 1998. Principles of Good Laboratory Practice (GLP) and Compliance Monitoring. http://www.oecd.org/document

${ }^{4}$ COUNCIL REGULATION (EC) No 440/2008 of 30 May 2008 laying down test methods pursuant to Regulation (EC) No 1907/2006 of the European Parliament and of the Council on the Registration, Evaluation, Authorisation and Restriction of Chemicals (REACH)
} 
National Food Institute

\section{Data and Methodologies}

\subsection{Data for Lot $2-$ toxicological studies and animal feeding studies}

In accordance with the purpose of Lot 2 of the Contract, data submitted to the Contractor included 28-day repeated oral toxicity studies in rodents on newly expressed proteins and 90-day feeding studies in rodents on whole food/feed.

\subsection{Methodologies}

In accordance with the scope of this contract, the Contractor was requested to check that toxicological studies and animal feeding studies provided in GMO applications submitted under Regulation (EC) No 1829/2003 fulfilled requirements of EFSA GMO Panel Guidance (EFSA, 2011a), and the EFSA Scientific Committee Guidance on conducting repeated-dose 90-day oral toxicity study in rodents on whole food/feed (EFSA, 2011b) and in Regulation (EU) No 503/2013. The check included verification that technical requirements by other relevant regulations and guidelines (including Directive 2004/10/EC ${ }^{5}$, OECD Principles of GLP ${ }^{6}$, Regulation (EC) 440/2008 ${ }^{7}$ ) are fulfilled.

Specifically the Contractor provided for each study submitted by EFSA:

1. detailed description of the adherence of the toxicological studies to the appropriate guidelines;

2. identification of potential lack of adherence to the appropriate guideline documents in the toxicological studies that can result in questions to complement their assessment;

3. a summary report and a power point presentation highlighting the main issues in terms of design of the study and adherence to relevant guidelines and legislation; this covered abstract, summary, statistics, reports of compliance and deviations to the respective relevant guidelines.

A kick-off meeting with EFSA representatives (Procurement team and the scientific officers acting as contact persons for the contract) took place in Parma at the 19 February 2015. Templates for the compliance checklist of 28-day toxicity studies on newly expressed proteins and of 90-day toxicity studies in rodents on whole food/feed towards the relevant EFSA guidance documents and OECD Technical guidance documents were developed. These templates supported the check for adherence of 90-day studies on GM food/feed in rodents to the recommendations given by EFSA guidance documents (EFSA, GMO Panel 2011; EFSA Scientific Committee, 2011, EFSA, 2014); to OECD TG 408 (1998); to GLP (OECD, 1998, EC, 2004), incorporated into Implementing Regulation (EU) No $503 / 2013$.

\footnotetext{
${ }^{5}$ EC, 2004. Directive 2004/10/EC of the European Parliament and of the Council of 11 February 2004 on the harmonisation of laws, regulations and administrative provisions relating to the application of the principles of good laboratory practice and the verification of their applications for tests on chemical substances. Official Journal of the European Union, L50, 44-59.

${ }^{6}$ OECD, 1998. Principles of Good Laboratory Practice (GLP) and Compliance Monitoring. http://www.oecd.org/document

7 COUNCIL REGULATION (EC) No 440/2008 of 30 May 2008 laying down test methods pursuant to Regulation (EC) No 1907/2006 of the European Parliament and of the Council on the Registration, Evaluation, Authorisation and Restriction of Chemicals (REACH)
} 
National Food Institute

\section{Assessment/results}

Using the agreed checklists, in the period covered by this report $(1 / 3 / 2017-27 / 11 / 2018)$ the Contractor finalised the assessment of the adherence to relevant guidelines of four 28-day studies and 12 90-day studies included in six GMO applications submitted to EFSA under Regulation No 1829/2003 (Table 1).

Table 1: EFSA contract OC/EFSA/GMO/2014/01, Lot 2. Studies evaluated by the Contractor during the period $01 / 03 / 17$ to $27 / 11 / 201828 / 02 / 17$

\begin{tabular}{|c|c|c|c|}
\hline Application no & EFSA-Q-no & Study type & Submission date ${ }^{a}$ \\
\hline AP109 & EFSA-Q-2012-00617 & 28-day & August 30, 2017 \\
\hline AP121 & EFSA-Q-2014-00719 & 90-day & March 2017 \\
\hline AP133 & EFSA-Q-2016-00583 & 90-day & January/February 2017 \\
\hline \multirow{3}{*}{ AP135 } & \multirow{3}{*}{ EFSA-Q-2016-00688 } & 90-day & January/February 2017 \\
\hline & & 90-day & \multirow{2}{*}{ July 11,2018} \\
\hline & & 90-day & \\
\hline AP136 & EFSA-Q-2016-00707 & 90-day & March 1, 2017 \\
\hline AP137 & EFSA-Q-2016-00775 & 90-day & March 1, 2017 \\
\hline AP138 & EFSA-Q-2016-00857 & 90-day & March 1, 2017 \\
\hline \multirow{2}{*}{ AP140 } & \multirow{2}{*}{ EFSA-Q-2017-00263 } & 28-day & September 26, 2018 \\
\hline & & 90-day & February 7, 2018 \\
\hline \multirow{2}{*}{ AP142 } & \multirow{2}{*}{ EFSA-Q-2017-00398 } & 28-day & \multirow{2}{*}{ May 4, 2018} \\
\hline & & 90-day & \\
\hline AP143 & EFSA-Q-2017-00424 & 90-day & May 4, 2018 \\
\hline AP145 & EFSA-Q-2017-00487 & 90-day & May 4, 2018 \\
\hline RX-002 & EFSA-Q-2016-0047 & 28-day & October 30, 2018 \\
\hline
\end{tabular}

a. Date of submission of the studies by EFSA to the Contractor.

\section{Conclusions}

Based on comprehensive checklists developed by the Contractor in collaboration with the EFSA GMO Unit, in the period covered by this report (1/3/2017-27/11/2018) the Contractor has reviewed the adherence to the respective relevant guidelines of studies related to 14 applications for GM plants submitted under Regulation (EC) No 1829/2003, and provided a complete overview of each study covering abstract, summary, statistics, reports of compliance and deviations to the respective relevant guidelines. This preparatory work was performed on four 28-day studies on newly expressed proteins and 12 90-day studies in rodents on GM food/feed. 
National Food Institute

\section{References}

Commission Implementing Regulation (EU) No 503/2013 of 3 April 2013 on applications for authorisation of genetically modified food and feed in accordance with Regulation (EC) No 1829/2003 of the European Parliament and of the Council and amending Commission Regulations (EC) No 641/2004 and (EC) No 1981/2006

DIRECTIVE 2004/10/EC of the European Parliament and of the Council of 11 February 2004 on the harmonisation of laws, regulations and administrative provisions relating to the application of the principles of good laboratory practice and the verification of their applications for tests on chemical substances.

EFSA, 2011a. EFSA Panel on Genetically Modified Organisms (GMO): Scientific Opinion on Guidance for risk assessment of food and feed from genetically modified plants. EFSA Journal 2011; $9(5)$ : 2150. [37 pp.] doi:10.2903/j.efsa.2011.2150.

EFSA, 2011b. EFSA Scientific Committee: EFSA guidance on conducting repeated-dose 90-day oral toxicity study in rodents on whole food/feed. EFSA Journal 2011;9(12):2438 [21 pp.] doi:10.2903/j.efsa.2011.2438

EFSA, 2014. Explanatory statement for the applicability of the Guidance of the EFSA Scientific Committee on conducting repeated-dose 90-day oral toxicity study in rodents on whole food/feed for GMO risk assessment. EFSA Journal 2014;12(10):3871, 25 pp., doi:10.2903/j.efsa.2014.3871

OECD Principles of Good Laboratory Practice (as revised in 1997) Environment Directorate Organisation for Economic Co-operation and Development Paris 1998

OECD guidelines for the testing of chemicals 407 (1995) - Repeated Dose 28-Day Oral Toxicity Study in Rodents

OECD guidelines for the testing of chemicals 407 (2008) - Repeated Dose 28-Day Oral Toxicity Study in Rodents

OECD guideline for the testing of chemicals 408 (1998) - Repeated Dose 90-day Oral Toxicity Study in Rodents 